\title{
Školní projekty ve výuce přírodovědných předmětů
}

\author{
Milena Pouchová \\ Envigogika 2010/V/1- Recenzované články/ Reviewed Papers \\ Publikováno/Published 13. 05. 2010 \\ DOI: http://dx.doi.org/10.14712/18023061.49
}

\begin{abstract}
Abstrakt:
Článek se zabývá projektovým vyučováním jakožto prostředkem vhodným k naplňování obecných vzdělávacích cílů a utváření klíčových kompetencí žáků základní školy. $V$ první části se věnuje teoretickým východiskům projektové výuky. Poukazuje na rozdíly $\mathrm{v}$ pojetí americké pragmatické, československé reformní a soudobé české pedagogiky. V druhé části představuje současnou situaci ve školní praxi základní školy a zvláště se zaměřuje na začleňování projektů do výuky př́rodovědných předmětů. Třetí část príspěvku se zabývá kvantitativním výzkumem provedeným na reprezentativním vzorku základních škol. Představuje část výsledků týkajících se projektů ve výuce předmětů vzdělávací oblasti Člověk a príroda. Zkoumán byl počet uskutečněných projektů a jejich základní charakteristiky, například délka, počet zapojených učitelů, tř́íd a předmětů.
\end{abstract}

\section{Klíčová slova: \\ Školní projekty; přirodovědné předměty}

\section{Abstract:}

The new educational system uses a duplex curriculum model, thus offering enough room for new effective methods for developing a pupil's key competences. This article concerns project-based education, especially in science subjects in the second stage of primary school. In the first part, we are introduced to a theoretical and historical analysis of project-based educational concepts. It highlights differences in American pragmatic, Czechoslovak reformist, and contemporary Czech pedagogies. Further, it presents the partial results of a survey which was conducted in the 2008/2009 school year. A sample of 180 primary schools participated in the survey. The main part of the survey was a questionnaire addressed to teachers of physics, chemistry, biology and geography. The most important aim was to establish common characteristics of implemented projects and teachers' attitudes to project work. The survey is focused only on projects created by teachers or students of a school in question.

The survey concludes that $88 \%$ of schools implemented at least one project. Schools prefer short projects that last one week in total, which are implemented in one class only and within the framework of one science subject. Most of them are prepared and organized by one teacher only. The main reason is minimal communication among teachers in school and the difficult organization of the project work. 


\section{Key words:}

School projects; natural sciences classes 
Článek se zabývá projektovým vyučováním jakožto prostředkem vhodným k naplňování obecných vzdělávacích cílů a utváření klíčových kompetencí žáků základní školy. V první části se věnuje teoretickým východiskům projektové výuky. Poukazuje na rozdíly v pojetí americké pragmatické, československé reformní a soudobé české pedagogiky. V druhé části představuje současnou situaci ve školní praxi základní školy a zvláště se zaměřuje na začleňování projektů do výuky přírodovědných předmětů. Třetí část příspěvku se zabývá kvantitativním výzkumem provedeným na reprezentativním vzorku základních škol. Představuje část výsledků týkajících se projektů ve výuce předmětů vzdělávací oblasti Člověk a př́roda. Zkoumán byl počet uskutečněných projektů a jejich základní charakteristiky, např́klad délka, počet zapojených učitelů, tříd a předmětů.

\section{Úvod}

V soudobé školní praxi existuje celá řada pedagogických inovací, prostřednictvím nichž chtějí učitelé měnit a zkvalitňovat vyučování. Jednou z významných cest, jak překonávat nedostatky tradiční školy, je projektová výuka. Tato výchovně vzdělávací koncepce poskytuje žákovi dostatek prostoru, aby byl ve škole aktivní a sám rozvíjel své zkušenosti místo toho, aby byl jen pasivním pozorovatelem a posluchačem. Projektová výuka se snaží respektovat zájmy a potřeby žáků a přibližit školu realitě života. Staví se proti izolovanosti a roztř́štěnosti poznatků a klade dưraz na jejich aplikaci v praxi.

Mnoho teoretiků i pedagogů spatřuje v projektové výuce pouze zpestření školního života, jiní ji chápou, zejména v souvislosti s přijetím nových kurikulárních dokumentů, jako významnou strategii naplňování cílů základního vzdělávání a rozvíjení klíčových kompetencí. Práce na projektu spočívá v řešení reálných úkolů či problémů, které často mají interdisciplinární charakter a vyžadují tudíž spolupráci více oborů. Samostatné bádání zvyšuje zájem žáků o danou problematiku, učí je hlubšímu pochopení a pohledu na věci a jevy v souvislostech, z různých úhlů. Žáci se učí plánovat a organizovat svoji práci, přebírat za ni odpovědnost a obhajovat její výsledky i své názory.

Projektová výuka působí komplexně na osobnost žáka, nebot' rozvíjí nejen jeho znalosti, schopnosti a dovednosti, ale ovlivňuje také postoje a hodnotovou orientaci. Z tohoto pohledu se jeví jako vhodný nástroj k naplňování cílů environmentální výchovy.

\section{Teoretická východiska projektového vyučování}

\section{Historická pojetí}

Zrod projektového vyučování je spojen s americkou pragmatickou pedagogikou začátku 20. století. Její představitelé kritizovali pasivní učení založené na drilu a striktní disciplínu tradiční herbartovské školy. Hledali prostředky, jak překonat tato negativa a více přizpůsobit školu dítěti. Za otce projektové metody je považován americký filosof a pedagog John Dewey, který chápal učení jako proces aktivního získávání zkušeností a poznatek jako výsledek žákovy samostatné práce. Prosazoval zkušenostní a činnostní učení (princip learning by doing) (Singule, 1991).

Deweyho žák William H. Kilpatrick jeho myšlenky dále rozvinul a v roce 1918 napsal první ucelenou studii o projektovém vyučování "The project method". Jako projekt označuje každou plánovitou a samostatnou činnost žáků, na jejímž počátku stojí problém, který je tak blízký zájmům a potřebám žáků, že mají motivaci jej řešit. Řešení obnáší nejen fyzickou práci, jak navrhoval Dewey, ale i činnosti myšlenkové, jako např́klad nastudování informací z literatury. Žáci pracují samostatně, individuálně nebo ve skupinách. Učitel ustupuje do pozadí; v př́padě potřeby usměrňuje činnosti žáků a poskytuje jim rady a pomůcky. Projekt velmi často přirozeně integruje učivo více předmětů. Prací na projektových úkolech žáci rozvíjejí nejen vědomosti a dovednosti 
vztahující se k jednotlivým předmětům, ale především si osvojují obecné dovednosti, postoje a hodnoty důležité pro život ve společnosti. Podle Kilpatricka je žákův postoj k projektu, odpovědnost za splnění úkolu, míra žákovy samostatnosti dokonce důležitější než obsah projektu. Výchovný aspekt projektové výuky je pro pragmatickou pedagogiku velice podstatný. Společenské hledisko považuje za primární a za hlavní cíl si klade výchovu aktivních charakterních občanů demokratické společnosti. (Dvořáková, 2009).

V rámci projektu rozlišuje Kilpatrick několik kroků, které jsou přejímány i současnými autory:

1) Záměr (purposing) učitele nebo žáka plynoucí ze zájmu či potřeby. Jsou definována východiska, problémy a hlavní otázky, je třeba ujasnit cíle a smysl projektu.

2) Plánování (planning) zahrnuje formulaci dílčích otázek, problémů a úkolů. Učitel s žáky navrhuje konkrétní aktivity, metody a postupy, které by mohly vést $k$ cíli. Veškeré činnosti jsou zasazeny do časového plánu a rozděleny mezi skupiny či jednotlivce.

3) Provedení (executing) neboli vlastní realizace plánu. Žáci pracují samostatně, pedagog koordinuje a usměrňuje jejich činnost, vystupuje jako poradce.

4) Hodnocení (judging). Žáci představují a hodnotí výsledky své práce, porovnávají svá zjištění a výtvory, hledají souvislosti a vyvozují závěry (Valenta, Kasíková \& al., 1993).

Kilpatrickova koncepce našla své zastánce i kritiky, a to nejen na americké půdě. Z USA se záhy rozšířila do Evropy. Celkový přehled historického vývoje projektově orientované výuky přináší německá studie „Internationale Bibliographie zur Projektmethode in der Erziehung 1895 - 1982". Pomocí rozboru publikací vydaných k této problematice ve 40 zemích světa zjištuje, do jaké míry se pedagogiky jednotlivých zemí zmíněnou koncepcí zabývaly. Ukazuje, že rozvoj projektové metody probíhal i po 2. světové válce $v$ rámci tzv. reformního hnutí a $v$ zemích západní Evropy doznal vrcholu v 60. a 70. letech označovaných jako tzv. „inovativní doba”.

Do československých podmínek se projektová výuka dostala ve 20. letech 20 . století především díky významnému pedagogovi a psychologovi Václavu Př́nodovi, který uskutečnil několik studijních pobytů v USA a záhy se stal - spolu se Stanislavem Vránou, Rudolfem Žantou či Stanislavem Velinským - propagátorem projektové výuky v našich školách (Kratochvílová, 2006). Příhoda označuje projekt za žákủv vlastní podnik, který zahrnuje koncentrované úkoly obsahující učivo z jednoho či více předmětů. Projekt musí mít určitý praktický cíl a uspokojivé zakončení (Př́hoda, 1936). Žantovo chápání projektu je velice podobné. Považuje ho za účelně organizovaný souhrn myšlenek, seskupených kolem důležitého centra praktického vědění, směřující k určitému cíli (Žanta, 1934).

Stanislav Vrána, ředitel Masarykovy pokusné školy, se projektové metodě věnuje ve své knize Učebné metody z roku 1938. Zde definuje školní projekt jako podnik, který jde za určitým cílem a za jehož výsledky žák převzal odpovědnost. Autor podotýká, že pouze projekt vycházející ze zkušeností, zájmů a potřeb žáků je může oslovit natolik, že jej pojmou za vlastní, převezmou za něj odpovědnost a vyvinou maximální úsilí na cestě k vytyčenému cíli. Podle Vrány i jeho současníků je zájem žáka, vedle odpovědnosti, důležitým znakem projektové výuky a rovněž její podmínkou. Velinský přiliš nevěří v sílu vnitřní motivace žáka. Domnívá se, že žáci primárně nemají zájem o mnoho dưležitých věcí, a proto má být hlavním úkolem učitele zájem navodit, a to pokud možno trvalý a nikoliv jen okamžitý. Velinský píše: „Projekt je určitě a jasně navržený úkol, který mưžeme předložiti žáku tak, aby se mu zdál životně důležitý tím, že se blíží skutečné činnosti lidí v životě." (1931). 
Hlavní rysy projektu v pojetí představitelů české reformní pedagogiky můžeme shrnout následovně:

- J Je to komplexní úkol koncentrovaný kolem určité myšlenky.

- Má vztah k běžnému životu.

- Jde za určitým předem stanoveným cílem.

- Je blízký zájmům a potřebám žáků.

- Z Žáci v něm pracují samostatně a přejímají odpovědnost za vlastní učení.

Spontánních projektů iniciovaných samotnými žáky ovšem postupem času ubývalo, zejména proto, že byly časově náročné a jejich délka se dala dopředu jen těžko odhadnout. Vystřídaly je projekty, které učitel dopředu připravil především tak, aby integrovaly učivo více předmětů. Projekty tak přestaly být orientovány na žáka a místo toho se orientovaly na obsah vyučování. Učitel přebíral zpět iniciativu a míra žákovské svobody a aktivity se snižovala. Mnohé školy neměly dostatečné materiální zázemí (školní zahrady, skleníky, dílny a podobně.), a tak jejich projekty byly jen minimálně založeny na praktických činnostech. Těmito úpravami se realizace projektového vyučování $v$ českých podmínkách postupně odkláněla od původních amerických principů. Nástup komunistické moci po druhé světové válce znamenal pozastavení myšlenek reformního pedagogického hnutí a zavření pokusných škol. Projektové vyučování bylo též kritizováno, nejvíce za to, že nerespektovalo didaktickou zásadu systematičnosti a posloupnosti učiva (Kratochvílová, 2006).

\section{Soudobá pojetí}

Po návratu k demokracii v 90. letech 20. století česká pedagogika čerpala, spíše než z americké pragmatické pedagogiky nebo československé reformní pedagogiky, z překladů moderní zahraniční literatury (např. Petty, Kovaliková, Tonucci). Základní problém však spočival v tom, že uvedené publikace obsahovaly především konkrétní př́klady projektů a sloužily učitelům jako návod pro plánování a realizaci projektů, ovšem nezabývaly se teoretickou analýzou projektového vyučování (Dvořáková, 2009).

Doposud neexistuje v české pedagogické literatuře úplná jednotná definice, která by popsala projektové vyučování $v$ celém jeho multidimenzionálním rozměru se všemi jeho aspekty, a na které by se shodla většina odborníků. Chápání projektového vyučování se liší u různých autorů v počtu, charakteru a akcentování jeho jednotlivých znaků. Mnozí autoři píšící o projektovém vyučování jej vůbec nedefinují.

V nejnovějším vydání pedagogického slovníku (Průcha, Walterová \& Mareš, 2003) je projektové vyučování definováno jako "vyučování založené na projektové metodě". Ta je popsána jako "metoda, v níž jsou žáci vedeni k samostatnému zpracování určitých projektů a získávají zkušenosti praktickou činností a experimentováním. Projekty mohou mít formu integrovaných témat, praktických problémů ze životní reality nebo praktické činnosti vedoucí k vytvoření nějakého výrobku, výtvarného či slovesného produktu." Hesla projekt či školní projekt slovník neobsahuje.

Jedna z prvních teoretických studií o projektovém vyučování byla publikována v roce 1993 (Valenta, Kasíková \& al., 1993). Projekt je zde představován jako organizovaná a cílená činnost s dưrazem na žákovskou odpovědnost. Autoři jmenují tyto hlavní principy projektového vyučování:

- zřetel k potřebám a zájmům dítěte

- zřetel k aktuální situaci ve školním prostředí nebo blízkém i širším okolí

- $\quad$ interdisciplinarita 
- $\quad$ seberegulace při učení

- orientace na produkt

- skupinová realizace

- společenská relevantnost (Valenta, Kasíková \& al., 1993).

V samostatné publikaci se Kasíková (1997) věnuje kooperativnímu vyučování, které vidí jako podklad pro projektovou práci. Projekt charakterizuje jako specifický typ učebního úkolu, ve kterém mají žáci možnost volby tématu a směru jeho zkoumání, a jehož výsledek je tudíž jen do určité míry předvídatelný. Vyžaduje iniciativu, kreativitu a organizační dovednosti, stejně tak jako převzetí zodpovědnosti za řešení problémů spojených s tématem. Projektové vyučování podle ní znamená posun od školy transmitivní, kde žák pasivně přejímá od učitele hotové vědění, ke škole konstruktivní, v níz žák své vědění sám konstruuje na základě předchozích zkušeností.

Kašová (1995) ve své knize popisuje zkušenosti s projektovou výukou z pokusné školy z Obříství a používá termín výchovně vzdělávací projekt. $V$ jeho počátku stojí konkrétní aktuální situace či problémy pocházející z bezprostředního okolí dětí. Řešení spočívá ve společném provádění předem naplánovaných činností směřujících $\mathrm{k}$ vytyčenému cíli (např. vytvořit u školy arboretum). Důležitý je přitom fakt, že se žáci přesvědčují o použitelnosti poznatků z různých vyučovacích předmětů a o jejich vzájemném propojení (Kašová, 1995).

Teorií i praxí projektové výuky v našich podmínkách se zabývá kniha Kratochvílové (2006). Autorka definuje jak projektovou metodu, tak projekt. Projektovou metodu považuje za uspořádaný systém činností učitele a žáků, $v$ němž dominantní roli mají učební aktivity žáků a podpưrnou roli mají poradenské činnosti učitele, kterými směřují společně $\mathrm{k}$ dosažení cílů a smyslu projektu. Komplexnost činností vyžaduje využití různých dílčích metod výuky a různých forem práce. Projekt je podle autorky komplexní úkol (problém), spjatý s životní realitou, s nímž se žák identifikuje a přebírá za něj odpovědnost, aby svou teoretickou i praktickou činností dosáhl výsledného žádoucího produktu (výstupu) projektu, pro jehož obhajobu a hodnocení má argumenty, které vycházejí ze získané zkušenosti (Kratochvílová, 2006).

Nejnovější studie (Dvořáková, 2009; Tomková, Kašová \& Dvořáková, 2009) pocházejí z období kurikulární reformy a berou v úvahu nové strategie vzdělávání v České republice. Dvořáková obecně definuje projektové vyučování jako specifický model vyučování, ve kterém žák převzal zodpovědnost za svůj úkol a samostatně realizuje konkrétní produkt. Obsahovým základem projektu je téma ze života, které přirozeně sdružuje poznatky $z$ různých oborů. Realizace zahrnuje teoretické i praktické činnosti. Konečný produkt dává práci smysl, motivuje žáka k činnosti. Vnitřní motivace je považována za nejdůležitější podmínku.

Z výše uvedeného je patrné, že existuje jen několik rysů projektové výuky, na nichž se všichni současní autoři shodují:

- Podstatou je řešení úkolu či problému spjatého s životní realitou.

- Činnosti směřují k předem vytyčenému cíli.

- Žáci pracuji samostatně, zpravidla ve skupinách a přebírají odpovědnost za práci.

Ne všichni autoři tedy kladou dưraz na praktické činnosti žáků a na koncentraci poznatků z různých oborù. Rovněž nevyžadují, aby projektový úkol žáky z podstaty zajímal. Někteří autoři se domnívají, že je hlavním úkolem učitele dostatečně motivovat 
žáky a zájem vyvolat. U všech autorů se setkáme s respektováním průběhu projektu v krocích, které navrhnul Kilpatrick. Někteří vymezují jako samostatnou fázi prezentaci dílčích nebo konečných produktů práce.

Otázkou zůstává, nakolik se tato pojetí shodují s projektovou výukou, kterou učitelé ve skutečnosti realizují.

\section{Projektové vyučování v současné praxi základní školy}

Projektové vyučování bylo již od počátku 90. let mezi učiteli velmi diskutováno a intuitivně zkoušeno i bez znalosti jeho teorie a historie. Učitelé vycházeli ze svých vlastních zkušeností a nápadů. Postupně je nepřímo inspirovaly semináře dramatické výchovy, ekologické výchovy a globální výchovy, které mají k projektovému vyučování a integrování vzdělávacích obsahư velmi blízko. Jednou z bariér při prosazování projektové výuky byla školská legislativa, která např́klad striktně předepisovala 45-ti minutovou vyučovací hodinu, pevné učební plány a klasifikaci pomocí známek. Určité uvolnění představovaly vzdělávací programy Obecná škola a Národní škola (Dvořáková, 2009).

Podstatný zlom přinesl Národní program rozvoje vzdělávání v České republice (tzv. Bílá kniha), Rámcový vzdělávací program pro základní vzdělávání (2001 - 2005) a nový školský zákon (2005). Kurikulární reforma posílila pravomoci a zodpovědnost jednotlivých škol v mnoha oblastech. Uvedené dokumenty dovolují učitelům a ředitelům začlenit do školního vzdělávacího programu projektové vyučování jako jednu ze strategií rozvíjení žákovských kompetencí. Do běžné praxe tak mohou vstoupit prvky, dříve označované jako inovativní a uplatňované jen na pokusných školách se souhlasem MŠMT. Pro realizaci projektového vyučování je důležitá například možnost blokové výuky, dělení třídního kolektivu na menší paralelní skupiny, přemistování a seskupování učiva $v$ rámci vzdělávacích oblastí, více disponibilních hodin pro nepovinné a povinně volitelné předměty, slovní hodnocení atd.

Existují tři hlavní možnosti, jak napInit průřezové téma Environmentální výchova (PT EV). První možností je včlenění obsahu PT EV do již existujících vyučovacích předmětů. Typická je integrace do předmětů vzdělávací oblasti Člověk a příroda, kde již řada očekávaných výstupů propojení s EV naznačuje. Druhou možností je vytvoření samostatného vyučovacího předmětu s vlastní časovou dotací, cíli a očekávanými výstupy. $\checkmark$ tomto případě je velmi náročné uchopit PT EV $v$ celé jeho šíri s presahem do mnoha dalších vzdělávacích oborů. Třetí cestou je realizace různě dlouhých projektů, uskutečněných v rámci jednoho nebo i více předmětů (Janoušková, 2005).

Před započetím kurikulární reformy a v jejím průběhu bylo uskutečněno několik výzkumů zaměřených na využívání projektového vyučování ve školní praxi. Většina z nich se orientovala na první stupeň základních škol a jejich výsledky byly zveřejněny $v$ různých bakalářských, diplomových či disertačních pracích. Bohužel tyto výzkumy nebyly provedeny na reprezentativních vzorcích škol či učitelů, a proto nemohly poskytnout informace o reálném stavu využívání projektového vyučování v českých školách.

Zajímavý výzkum provedla Kratochvílová (2006). Jednalo se o kvalitativní šetření zaměřené na učitelovo pojetí projektové výuky a projektů. Výběrový soubor tvořilo ve výzkumu 29 záměrně vybraných pedagogů (z prvního i druhého stupně 18-ti základních škol), kteří již měli s projektovou výukou zkušenosti. Autorku zajímalo, co si učitelé představují pod pojmy "projekt” a „projektová výuka” a jaké je jejich chápání některých aspektů tohoto zpưsobu práce. Zvolenou metodou byla analýza textů volného psaní a myšlenkových map. Z vyhodnocení vyplynula následující pojetí projektové výuky včetně hlavních aspektů:

- Je jednou z metod či forem školní práce. 
- Má prínos pro komplexní rozvoj osobnosti dítěte.

- Projekty mohou mít různou dobu trvání, od jediné vyučovací hodiny až po celý školní rok.

- Projekty mohou zahrnovat učivo jednoho či více předmětů.

- Projekty mohou být realizovány v rámci jedné nebo více tříd.

- Učitel detailně připravuje projekt a navrhuje jej žákům, v realizační fázi má roli poradce.

- Základem projektu je práce žáků ve skupinách.

- Projekt je koncipován podle učiva $v$ předmětu či ročníku, dále podle vyspělosti dětí.

- Koncentračním jádrem projektu je téma dané osnovami, př́padně úkoly a problémy praktického života či významné události.

Z výše uvedeného je patrné, že pojetí učitelů ve výzkumném vzorku se podstatně liší od pojetí teoretiků projektové výuky. Učitelé si uvědomují, že projektová výuka rozvíjí mnoho stránek osobnosti dítěte. I přesto však zaměřují své projekty na učivo stanovené osnovami a nikoliv na žáka, jeho zájmy a potřeby. Cílem je probrat potřebné učivo zábavnou formou. Učitel navíc detailně připravuje projekt dopředu bez účasti žáků a teprve potom se je snaží pro daný úkol motivovat. Projekt tak přestává být „podnikem žáka" a je spíše podnikem učitele.

Odlišný výzkum byl realizován v roce 2001 pracovníky PřF UK a PedF UK v Praze. Jednalo se o rozsáhlý výzkum zaměřený na zařazování projektů do výuky př́rodovědných předmětů. Přestože výzkumný vzorek byl dostatečně velký, výzkum nemůže být považován za reprezentativní vzhledem ke způsobu výběru respondentů a vzhledem $\mathrm{k}$ tomu, že pojem projekt nebyl ve výzkumu jasně vymezen. Dotazníkového šetření se zúčastnilo v první fázi 130 učitelů prírodopisu, zeměpisu, chemie a fyziky ze základních škol. Jednalo se o účastníky seminářů a přednášek pořádaných pro učitele př́rodovědných předmětů. $\vee$ druhé fázi se realizátoři projektů dotazovali 128 fakultních učitelů různých aprobací. $\vee$ časopise Pedagogika publikovali autoři mimo jiné tato zjištění:

- $12 \%$ respondentů z prvního souboru a $40 \quad \% \quad z$ druhého souboru realizovalo převzaté projekty vytvořené jinými organizacemi. Nejčastěji zmiňovanými byly projekty Sdružení pro ekologickou výchovu Tereza.

- $12 \%$ respondentů z prvního souboru a více než 50 \% z druhého souboru realizovalo projekty, které sami vytvořili.

Autoři př́spěvku $v$ závěru konstatují, že projektové vyučování pozvolna nachází uplatnění v základních školách, že učitelé mají zájem zařazovat projekty do své výuky a také se v této problematice vzdělávat (Švecová \& al., 2003).

Jelikož zmíněný výzkum byl realizován ještě před uvedením kurikulární reformy do praxe, rozhodli jsme se provést na zhruba stejně velkém, ovšem reprezentativním, vzorku nový průzkum, který by poskytnul aktuální vhled do problematiky. 


\section{Výzkum}

\section{Zaměření výzkumu}

Prezentovaný výzkum byl zaměřen na projekty uskutečněné na 2 . stupních základních škol v rámci předmětů vzdělávací oblasti Člověk a př́roda. Na rozdíl od Švecové a kol. jsme se orientovali výhradně na projekty vytvořené přímo ve školách. Stěžejní část výzkumu proběhla $v$ červnu 2009, jelikož byla zaměřena na projekty uskutečněné během školního roku 2008/09. Zajímalo nás nejen, v jaké míre byly projekty ve školách realizovány a jaké typy projektů převažovaly, ale také, jaké názory mají na tuto formu výuky samotní učitelé.

Základní operační pojmy byly ve výzkumu definovány ${ }^{1}$ takto:

Přírodovědné předměty = všechny předměty (vzdělávací obory), které Rámcový vzdělávací program pro základní vzdělávání zahrnuje do vzdělávací oblasti Člověk a príroda, tj. Fyzika, Chemie, Přírodopis a Zeměpis, případně další, školami vytvořené předměty, které svou charakteristikou, cíli a očekávanými výstupy této oblasti odpovídají.

Projekt $=$ komplexní úkol, na němž žáci pracují samostatně, alespoň částečně $\checkmark$ týmech či skupinách; učitel jejich činnost pouze koordinuje, usměrňuje a hodnotí. Činnosti se uskutečňují v těchto krocích: záměr, plánování, provedení, hodnocení.

Př́rodovědný projekt = projekt zahrnující vzdělávací obsah (cíle, očekávané výstupy) alespoň jednoho prírodovědného předmětu.

Z těchto předpokladů vycházela také specifikace projektu pro samotné učitele. Úvodní instrukce dotazníku obsahovala vymezení pojmů "prírodovědné předměty" a "prírodovědný projekt" a dále stanovila čtyři nezbytné podmínky, které musí projekty splňovat ${ }^{2}$ :

1) byly vytvořeny učiteli nebo žáky dané školy (tedy ne projekty připravené jinými organizacemi)

2) žáci v nich pracovali samostatně, učitel jejich činnost pouze koordinoval, usměrňoval, hodnotil

3) žáci v nich pracovali alespoň částečně v týmech či skupinách

4) Činnosti probíhaly v těchto fázích: záměr, plánování, provedení plánu, hodnocení.

Prezentované výsledky výzkumu vychází z těchto výzkumných otázek:

- Jaký je podíl škol, jež realizovaly prírodovědné projekty ve školním roce 2008/09, na celkovém počtu škol?

- Kolik př́rodovědných projektů se na školách uskutečnilo?

- Jaké typy projektů byly preferovány? (Zde jsme vycházeli z typologie Kratochvílové (2006), která uvádí dělení projektů podle následujících hledisek: délka, počet zúčastněných tříd, počet zapojených předmětů, navrhovatel - pưvodce projektu, prostředí projektu.)

\footnotetext{
${ }^{1}$ Byly obsaženy $v$ hlavičce dotazníku - viz příloha

2 Tyto podmínky byly uvedeny $v$ hlavičce dotazníku (viz př́loha). Podmínka týkající se realizace ve školním roce $2008 / 9$ byla obsažena již v prưvodním mailu a také byla zmíněna zvlášt' u každé položky. (Protože některé položky se týkají všech projektů bez ohledu na termín realizace)
} 
- Do jaké míry byl počet př́rodovědných projektů závislý na počtu učitelů prírodovědných předmětů?

\section{Metoda}

Vzhledem k charakteru požadovaných informací a vzhledem ke značnému rozsahu výzkumného souboru byl ke sběru dat použit dotazník vlastní konstrukce, ověřený v předvýzkumu na vzorku 20 respondentů. Po finálních úpravách dotazník obsahoval 49 uzavřených a 4 otevřené otázky. Část výsledků výzkumu představíme na následujících rádcích.

Zde uvádíme konkrétní znění otázek, jejichž vyhodnocení článek přináší. Číslování otázek odpovídá původnímu pořadí v dotazníku.

1) Počet obyvatel obce, ve které se Vaše škola nachází, je
A) méně než 10000
B) $10000-50000$
C) $50000-300000$
D) více než 300000

3) Kolik učitelů přírodovědných předmětů působí ve Vaší škole?

\section{4) Kolik přírodovědných projektů, splňujících čtyři výše uvedené podmínky, proběhlo v letošním školním roce ve Vaší škole?}
a) žádný
b) jeden
c) dva
d) více než dva - uved'te počet: .....

6) Pro kolik přírodovědných projektů realizovaných $\mathbf{v}$ tomto školním roce platí následující charakteristiky? Do posledního sloupce vždy uvedte čílem (včetně nuly) počet všech projektů splňujících danou charakteristiku.

\begin{tabular}{|l|l|l|}
\hline 6.1 & trval jednu hodinu & \\
\hline 6.2 & trval několik hodin v jediném dni & \\
\hline 6.3 & trval více než den a maximálně 7 dní & \\
\hline 6.4 & trval 8 dní až 28 dní & \\
\hline 6.5 & trval déle než 4 týdny & \\
\hline 6.6 & účastnili se ho žáci jedné třídy & \\
\hline 6.7 & účastnili se ho žáci více tříd stejného ročníku & \\
\hline 6.8 & účastnili se ho žáci více tříd různých ročníků & \\
\hline 6.9 & účastnil se ho jeden učitel & \\
\hline 6.10 & byl uskutečněn v rámci jednoho přírodovědného předmětu & \\
\hline 6.11 & byl uskutečněn v rámci více přírodovědných předmětů & \\
\hline 6.12 & $\begin{array}{l}\text { zahrnoval účast alespoň jednoho ne-přírodovědného předmětu (společenské } \\
\text { vědy atp.) }\end{array}$ & \\
\hline 6.13 & vyžadoval úpravu pravidelného denního rozvrhu hodin & \\
\hline 6.14 & probíhal alespoň částečně mimo areál školy & \\
\hline
\end{tabular}


Školy byly požádány o spolupráci v červnu 2009 prostřednictvím emailu. Dotazník byl směřován učitelům předmětů vzdělávací oblasti Člověk a př́roda. Pedagogové mohli dotazník vyplnit dvěma způsoby - přímo na internetových stránkách organizátorů nebo $v$ přiloženém textovém souboru a následně odeslat zpět na kontaktní emailovou adresu. Za každou školu vyplňoval dotazník pouze jeden učitel prrírodovědných předmětů s tím, že uvedl údaje o projektech za celý druhý stupeň školy. $8.0 \mathrm{cz}$

Získané odpovědi byly zpracovány v programech Microsoft Excel 2007 a Statistica

\section{Základní a výběrový soubor}

Základní soubor tvořily všechny základní školy s 2 . stupněm vzdělávající žáky podle Rámcového vzdělávacího programu pro základní vzdělávání s př́lohou upravující vzdělávání žáků s lehkým mentálním postižením platného od 1. 9. 2005, bez ohledu na zřizovatele. Podle Statistické ročenky Ústavu pro informace ve vzdělávání a doplňujících informací jeho pracovníků bylo ke dni 30. září 2008 takových škol 2660. Z jejich kompletního adresáře bylo náhodným prostým (nestratifikovaným) výběrem vylosováno 250 škol spolu s jejich kontaktními emailovými adresami. Dotazník vyplnilo a poslalo zpět 182 škol. Jelikož dva dotazníky bylo nutné vyřadit, výběrový soubor nakonec tvořilo rovných 180 škol. Návratnost tedy činila $72 \%$.

Vyhodnocení první otázky ukázalo, že ve výběrovém souboru byly nejvíce zastoupeny ( $29 \%$ ) školy z obcí s méně než 10 tisíci obyvateli. Naopak nejméně odpovědí (19 \%) patřilo školám z měst nad 300 tisíc obyvatel, tedy z Prahy, Brna a Ostravy. Příslušnou otázku zodpověděly všechny školy výběrového souboru.

\section{Obr. č. 1: Počet obyvatel obce, v níž se školy nacházejí}

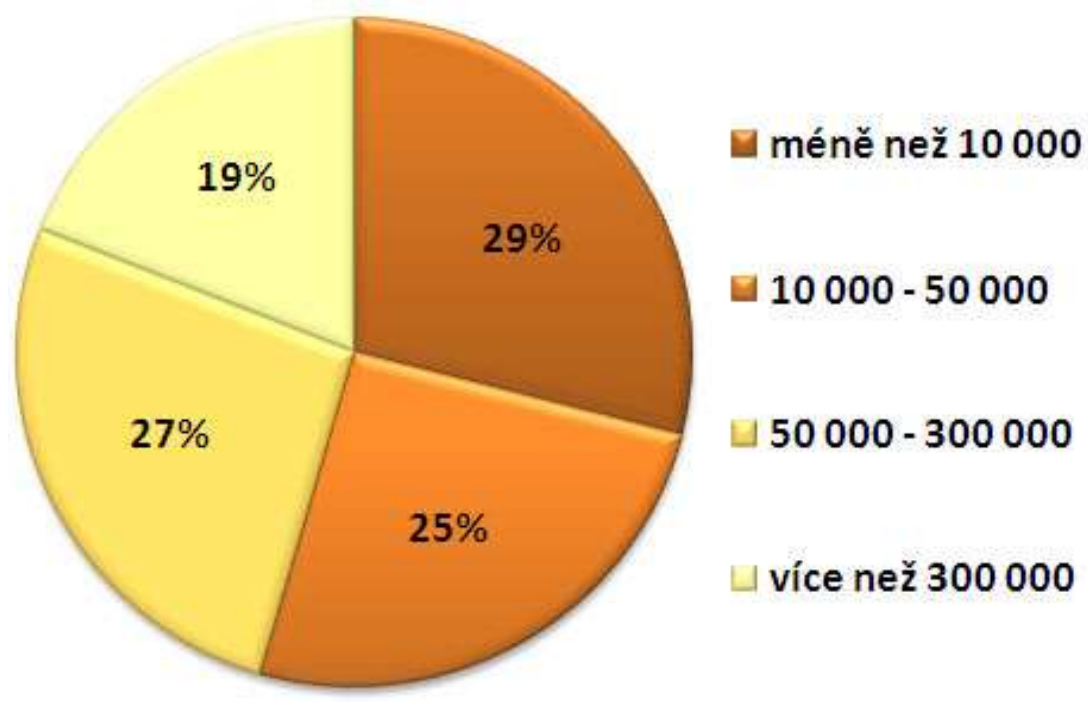




\section{Výsledky výzkumu}

Ze 180 škol, které dotazník vrátily vyplněný, realizovalo alespoň jeden projekt splňující výše uvedené podmínky rovných 160 škol, což činí 88,88 \%. Předpokládáme, že větší motivaci $k$ navrácení dotazníku měly ty školy, které se mohly nějakým projektem pochlubit. Proto byla vypočítána směrodatná odchylka $(\mathrm{SO}=3,72)$ a následně konfidenční interval spolehlivosti pro $95 \%$ hladinu významnosti. Konstatujeme, že skutečný počet škol realizujících prírodovědné projekty se pohybuje mezi 81,44 a 96,32 \%.

Školy, které se do průzkumu zapojily, uskutečnily $v$ př́rodovědných předmětech celkem 642 projektů, což činí průměr 3-4 projektu na jednu školu. Nejčastějším případem byla škola $s$ dvěma prírodovědnými projekty ( $24 \%$ škol). Rovněž počet škol, jež uskutečnily jediný projekt, byl vysoký (17 \%). Jak je patrné z obrázku č. 4 , největší počet projektů na jediné škole činil 26. Př́slušnou otázku týkající se počtu projektů zodpověděli všichni respondenti.

\section{Obr. č. 2: Počet projektů realizovaných v přírodovědných předmětech ve školním} roce 2008/09

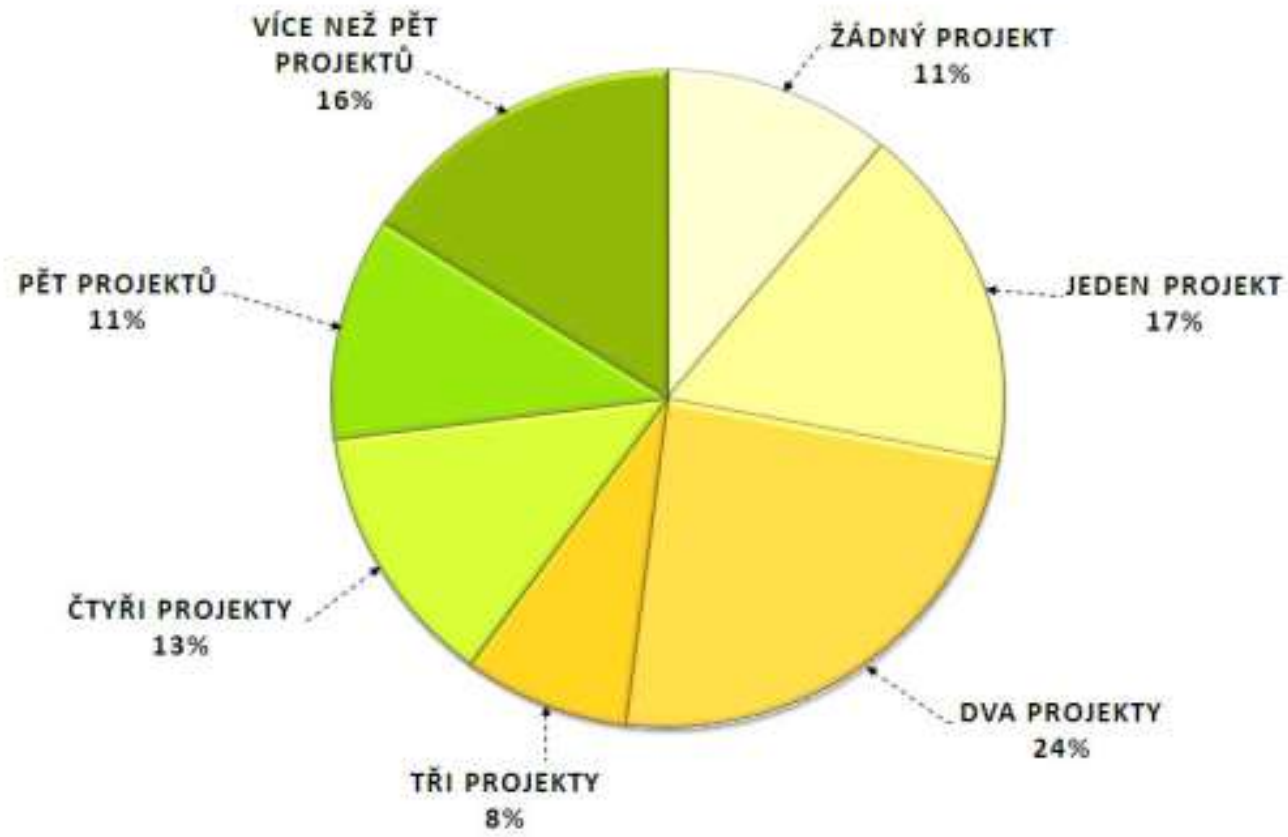

Na 180 školách působí celkem 950 učitelů přírodovědných předmětů. Na dvou z nich učí všechny tyto předměty pouze jediný učitel. Ve vzorku se vyskytlo i šest velkých škol, $v$ nichž působí deset učitelů se zmíněnými aprobacemi. Nejčastějším prípadem byla škola $s$ pěti učiteli př́rodovědných předmětů. 
Obr. č. 3: Počet učitelů přírodovědných předmětů

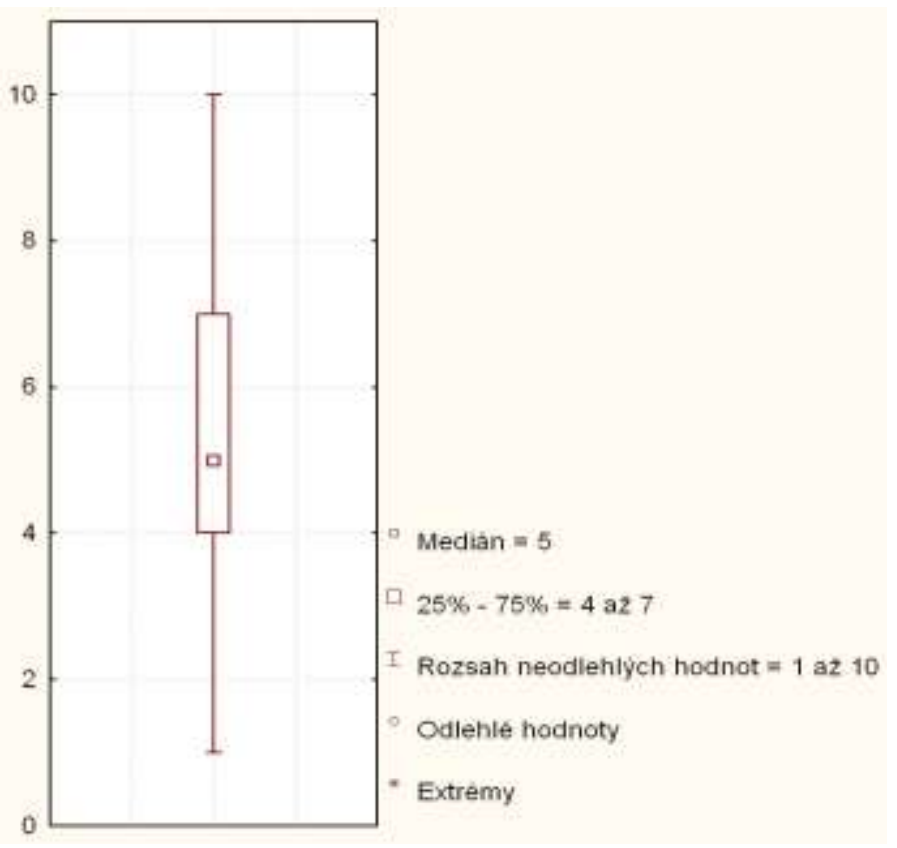

Obr. č. 4: Počet realizovaných projektů

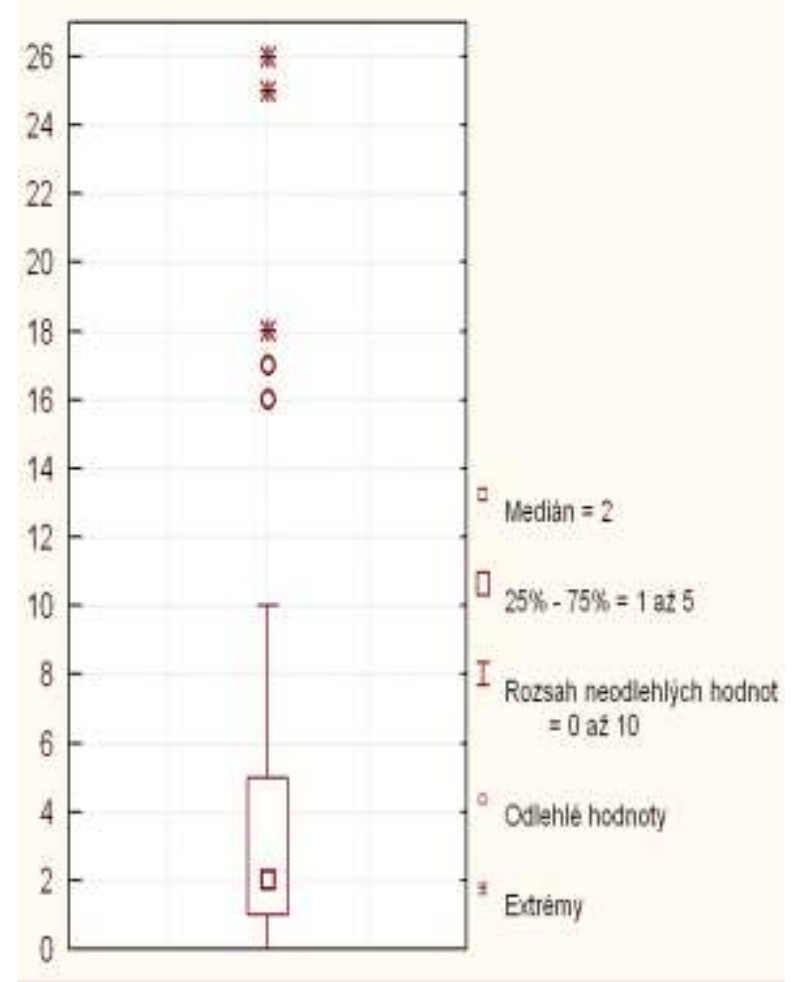

Obrázek č. 5 ukazuje vztah mezi počtem učitelů př́rodovědných předmětů a počtem realizovaných projektů. Velikost kroužků odpovídá četnostem jednotlivých kombinací. Nejčastějším př́padem byla škola se sedmi učiteli a dvěma uskutečněnými projekty, což je $v$ grafu vyznačeno červeným kroužkem. $Z$ výpočtu Pearsonova koeficientu korelace $\left(r_{p}=\right.$ 
$0,308)$ je patrné, že mezi sledovanými proměnnými je jen nízká pozitivní závislost. Počet projektů je ovlivněn počtem učitelů z $9 \%$ (koeficient determinace $=0,0948$ ). Pouze vzácně najdeme školy, které mají nízký počet učitelů, a přesto realizují hodně projektů. Celkově ve vzorku převažují školy s mnoha učiteli avšak s malým počtem projektů. Toto zjištění odpovídá výsledku jiné položky, která ukazuje, že 52 \% projektů se účastnil pouze jeden učitel bez spolupráce s kolegy.

\section{Obr. č. 5: Vztah mezi počtem učitelů přírodovědných předmětů a počtem} realizovaných projektů

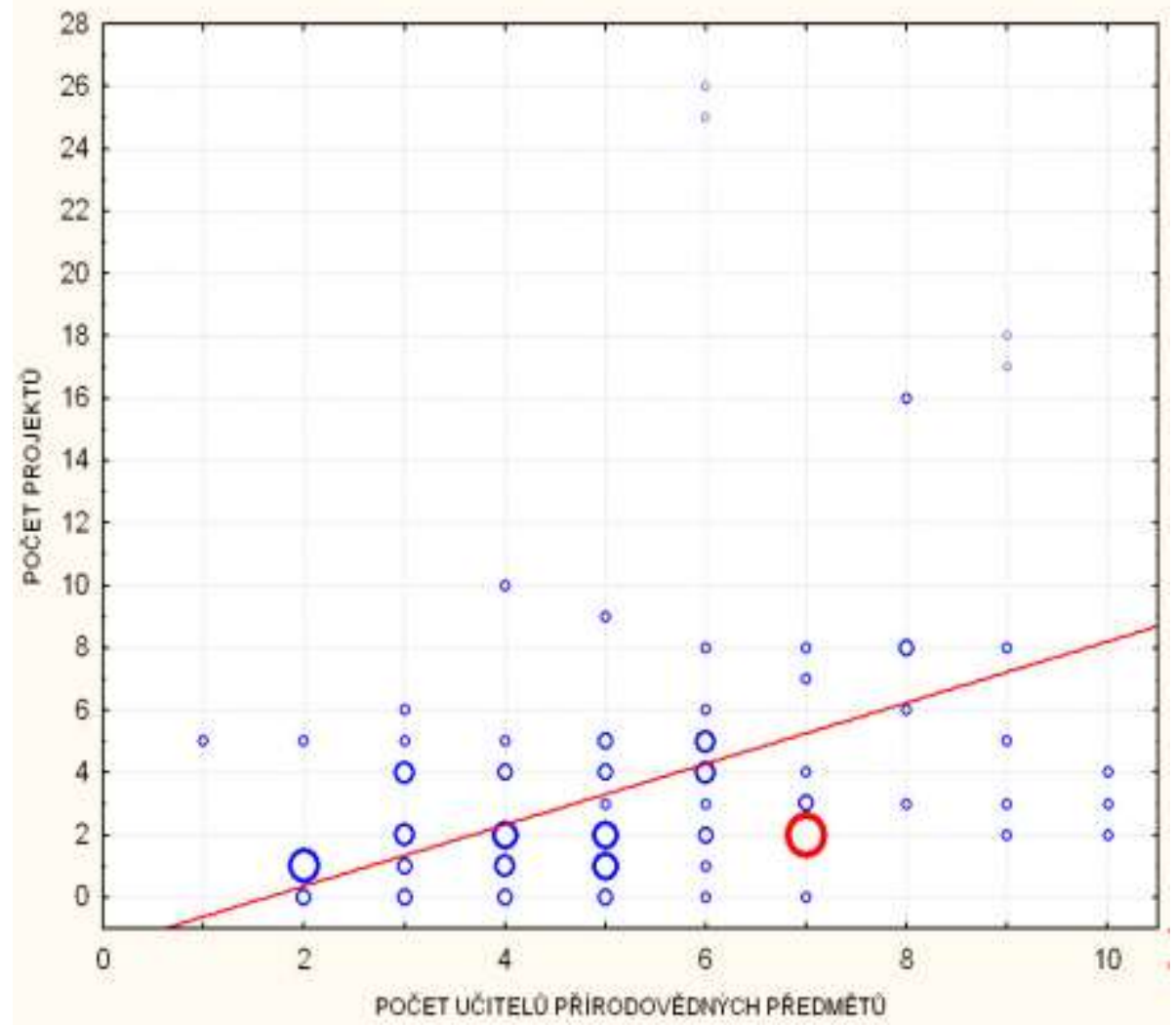

Další ze základních zjištovaných vlastností projektů byla jejich délka. Příslušnou otázku zodpověděli všichni respondenti. Nejvíce projektů (192 projektů, tj. 30 \%) bylo realizováno $v$ jediném dni. Školy realizují krátkodobé projekty většinou $v$ rámci předem vyhlášených projektových dnů, jichž se účastní všechny ročníky daného stupně či dokonce celé školy. Rovněž počet projektů trvajících dva až sedm dní byl vysoký (186 projektů, tj. $29 \%$ ). $15 \%$ všech projektů trvalo pouze jednu hodinu. 


\section{Obr. č. 6: Délka realizovaných projektů}

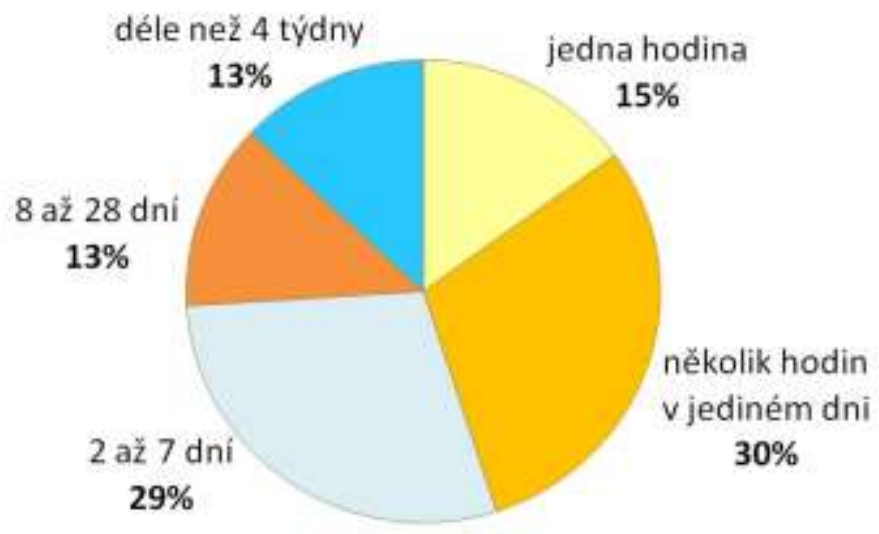

Zatímco jednodenní projekty většinou vyžadovaly úpravu pravidelného týdenního rozvrhu hodin, dlouhodobé projekty byly realizovány v obvyklých vyučovacích hodinách zapojených předmětů. 38 \% všech projektů probíhalo alespoň částečně mimo areál školy.

Z další otázky, kterou zodpovědělo $96 \%$ respondentů, vyplynulo, že dvě třetiny všech projektů (422 projektů) byly uskutečněny pouze $v$ rámci jednoho př́rodovědného předmětu, nejčastěji prírodopisu. Necelá jedna třetina projektů (30 \%) byla realizována v rámci více př́rodovědných předmětů. $29 \%$ všech projektů zahrnovalo také účast alespoň jednoho ne-přírodovědného předmětu (společenské vědy, jazyků, atp.)

Dále nás zajímal počet tříd zapojených do jednotlivých projektů. Ve $37 \%$ se jednalo o projekt uskutečněný pouze s žáky jediné třídy. $29 \%$ projektů se vyznačovalo účastí více trríd téhož ročníku a ve $34 \%$ případů byl projekt realizován i napříč více ročníky. Takové projekty jsou většinou realizovány $\mathrm{v}$ rámci celoškolních projektových dnů, jak již bylo uvedeno. Otázku zodpověděli všichni respondenti.

\section{Obr. č. 7: Rozsah projektů - počet zapojených tříd}

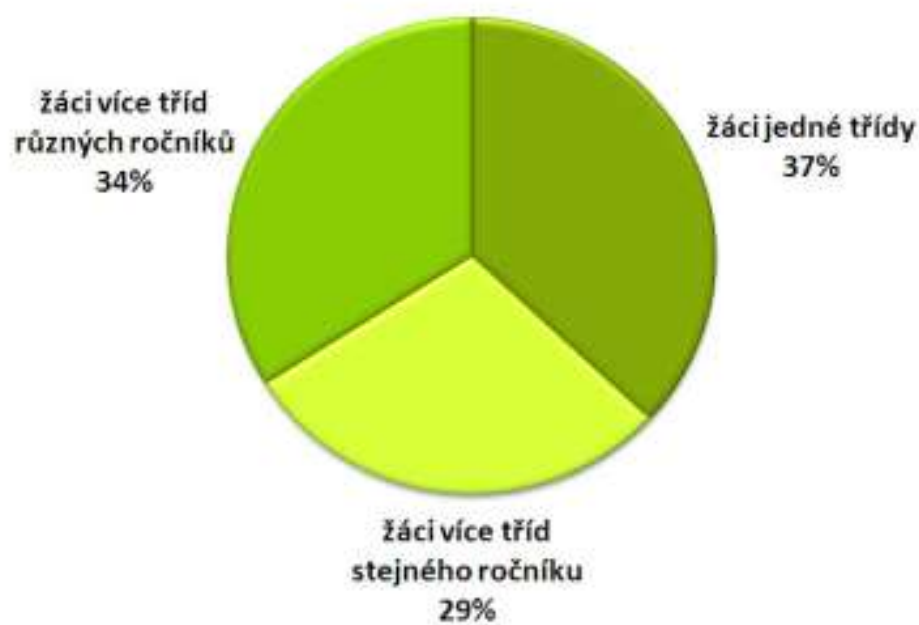


Původci - navrhovateli projektů byli v drtivé většině sami učitelé. Z položek zjištúujících míru aktivity žáků v jednotlivých fázích projektu vyplynulo, že žáci jsou nejméně aktivní právě $v$ počátečních fázích záměru a plánování. Učitelé uvedli, že pouze v $9 \%$ prípadů projekt vznikl jako nápad žáků a pouze ve $26 \%$ př́padů žáci sami vymýšleli zadání úkolu či navrhovali různé činnosti a pracovní postupy.

\section{Závěry a diskuze}

Dnešní škola stojí před těžkým úkolem, nebot' je na ni přenášena zodpovědnost i v oblastech, které byly ještě nedávno doménou jiných institucí, především rodiny. Žáci jsou obklopeni velkým množstvím informací, ale mají i hodně vlastních zkušeností, především z kontaktu s vrstevníky, rodiči, z cestování. Škola by měla pomoci žákovi orientovat se $v$ informacích, zpracovat a zhodnotit individuálně získané zkušenosti a zařadit je do celkového obrazu světa a pojetí vzdělání (Tomková, Kašová \& Dvořáková, 2009). Měla by žáka naučit samostatnému a odpovědnému rozhodování a jednání, spolupráci, pozitivnímu postoji k sobě samému i okolnímu světu, metodám řešení problémů a motivovat ho k celoživotnímu učení.

Ke splnění těchto požadavků může přispívat i projektové vyučování. $V$ jedné z úvodních kapitol Rámcového vzdělávacího programu pro základní vzdělávání je uvedeno: „Pojetí základního vzdělávání na 2. stupni je budováno na širokém rozvoji zájmů žáků, na vyšších učebních možnostech žáků a na provázanosti vzdělávání a života školy se životem mimo školu. To umožňuje využít náročnější metody práce i nové zdroje a způsoby poznávání, zadávat komplexnější a dlouhodobější úkoly či projekty a přenášet na žáky větší odpovědnost ve vzdělávání i v organizaci života školy."

Z našeho výzkumu vyplynulo, že více než 80 \% škol využívá projekty ve výuce prírodovědných předmětů. Zjistili jsme, že ve školách jsou upřednostňovány projekty

- $\quad$ krátkodobé, tj. jednodenní nebo maximálně týdenní

- realizované $v$ rámci jednoho předmětu

- realizované $v$ rámci jediné třídy

- $\quad$ připravené a organizované jedním učitelem.

V souladu s Dvořákovou (2009) konstatujeme, že učitelé často hovoří o projektovém vyučování i v situaci, kdy využívají jen některé z jeho znaků nebo etap. Přestože na základě teoretických studií byl pojem „projekt" pro účely výzkumu vymezen dosti široce, v praxi jej učitelé často používají za hranicemi i této široké definice, jak můžeme usuzovat z odpovědí na některé dotazníkové položky. Například pokládáme za vyloučené, aby se v jediné vyučovací hodině (tuto délku mělo $15 \%$ všech projektů) uskutečnily všechny 4 fáze projektu. Nepovzbudivé je rovněž zjištění ohledně žákovské aktivity v úvodních fázích projektu. Pouze necelá desetina projektů vznikla jako nápad žáků a jen ve čtvrtině př́padư žáci sami vymýšleli zadání úkolu či navrhovali různé činnosti a pracovní postupy. Učitelé připravují projekty dopředu, bez účasti žáků - $56 \%$ projektů bylo dokonce na začátku roku či pololetí zařazeno do tematického plánu. Potvrzuje se tak zjištění Kratochvílové (2006), která konstatuje odklon v pojetí projektu od podniku žáka k podniku učitele.

Projektová výuka v pojetí současné české pedagogické teorie se př́liš neliší od téměř sto let staré původní koncepce. Zásadně se však odlišuje od výuky, kterou realizují učitelé v praxi.

V současnosti chybí české pedagogické praxi výzkum, který by se zabýval efektivitou projektového vyučování. Nejen $v$ našem, ale také v ostatních výzkumech zaměřujících se 
na přednosti a úskalí projektové výuky, učitelé hojně uvádějí, že práce v projektu pomáhá rozvíjet většinu klíčových kompetencí. Nejčastěji hovoří o rozvoji samostatnosti, komunikačních a kooperativních schopností, o práci s informacemi a jejich zdroji a také o dovednostech prezentovat a obhájit svou práci a názory. V těchto oblastech je vliv projektového vyučování nesporný; plyne z faktu, že se žáci více či méně aktivně zapojují do výuky.

Co se týče konkrétních znalostí a dovedností v rámci jednotlivých předmětů, učitelé uvádějí, že některé poznatky jsou pevněji a trvaleji osvojeny. Nezmiňují se ovšem o jejich množství a také o tom, zda se jedná o poznatky podstatné či okrajové. Nebylo dosud prokázáno, zda je $v$ tomto směru projektová výuka efektivnější než klasické vyučovací metody, vzhledem k velkému množství vynaloženého času učitelova i žákova. Časová náročnost př́pravy, realizace i hodnocení projektové práce je totiž učiteli uváděna jako nejpalčivější úskalí. K prozkoumání této problematiky je zapotřebí dalších výzkumů, pravděpodobně pracných kvalitativních šetření s využitím experimentálních a kontrolních skupin.

\section{Související výzkum}

Další výsledky týkající se dotazníkových otázek, které nebyly analyzovány v článku pro Envigogiku, naleznou čtenáři v těchto publikacích:

1) V druhém letošním čísle časopisu Biologie - chemie - zeměpis (2010, roč. 19, č. 2, s. 113-116) vyšel článek s názvem JAK SE DAŘí PǨÍRODOVĚDNÝM PROJEKTƠM NA ZÁKLADNÍCH ŠKOLÁCH? Zabývá se především vyhodnocením dotazníkové položky č. 5 (tematické zaměření projektů)

2) Ve slovenském časopise Pedagogické rozhláady: POUCHOVÁ, Milena. Přednosti

a úskalí projektové výuky očima českých a slovenských učitelů. Pedagogické rozhl'ady. 2010, roč. 19, č. 2, s. 12-14. ISSN 1335-0404..

3) Kompletní výsledky budou součástí mé disertační práce Školní projekty ve výuce přírodovědných předmětů na základní škole (termín obhajoby: podzim 2010)

\section{Příloha - dotazník}

\section{Citovaná literatura:}

- Dvořáková, M. (2009). Projektové vyučování v české škole - vývoj, inspirace, současné problémy. Praha: Karolinum.

- Janoušková, S. (2005). Environmentální výchova v RVP ZV. . Retrieved from http://clanky.rvp.cz/clanek/c/ZKA/275/ENVIRONMENTALNI-VYCHOVA-V-RVP-ZV.html

- Kasíková, H. (2001). Kooperativní učení, kooperativní škola. Praha: Portál.

- Kašová, J. (1995). Škola trochu jinak. Projektové vyučování v teorii a praxi. Kroměříž: Iuventa.

- Kratochvílová, J. (2006). Teorie a praxe projektové výuky. Brno: MU.

- Lukavská, E. (2003). Pozor děti. Didaktické otázky vyučování orientovaného na dítě. Dobrá voda: Aleš Čeněk. 
- Naar, D., Koudelková, I., Zerzáňová, L., \& Slejšková, E. (2004). Průvodce pro projektové vyučování. Praha: Zajímavé učení. Egredior o.s..

- Průcha, J., Walterová, E., \& Mareš, J. (2003). Pedagogický slovník. Praha: Portál.

- Př́hoda, V. (1936). Reformní praxe školská. Praha: Československá grafická unie.

- Rámcový vzdělávací program pro základní vzdělávání s prílohou upravující vzdělávání žáků s lehkým mentálním postižením (2005). Praha: Výzkumný ústav pedagogický v Praze.

- Singule, F. (1991). Americká pragmatická pedagogika. John Dewey a jeho američtí následovníci. Praha: SPN.

- Schäfer, U. (1998). Internationale Bibliographie zur Projektmethode in der Erziehung. Berlin: VWB-Verlag für Wissenschaft und Bildung.

- Švecová, M., Beneš, P., Pumpr, V., \& Herink, J. (2003). Školní projekt jako kreativní forma výuky prírodovědných předmětů na základní a střední škole.Pedagogika, 53(4), 396-403.

- Tomková, A., Kašová, J., \& Dvořáková, M. (2009). Učíme v projektech. Praha: Portál.

- Valenta, J., Kasíková, H., Svobodová, E., Mašatová, M., Vybíral, M., Provazník, J., . . . Bláha, J. (1993). Pohledy. Projektová metoda ve škole a za školou. Praha: Ipos Artama.

- Velinský, S. (1946). Přibližme školu životu: Plán soustavy životosměrného školení. : Společnost pro individualizaci výchovy.

- Vrána, S. (1936). Učebné metody. Brno-Praha: Sdružení Dědictví Komenského z Prahy ve spolupráci s Vydavatelským odborem Ú.S.J.U. v Brně.

- Žanta, R. (1934). Projektová metoda: Pokus o řešení pracovní školy. : Praha.

\section{Další literatura k teorii a praxi projektové výuky:}

- $\quad$ COWAN, George. Project work in the secenodary school. London: Longmans, 1967. $91 \mathrm{~s}$. bez ISBN

- DEWEY, John. Škola a společnost: tři přednášky. přeložil Jan Mrazík. Praha: nakladatelství Laichter, 1904. 99 s. bez ISBN

- $\quad$ GRECMANOVÁ, Helena; URBANOVSKÁ, Eva. Projektové vyučování a jeho význam v současné škole. Pedagogika. 1997, roč. 47, č. 1, s. 37-45. ISSN 3330-3815.

- HRIŇÁK, Martin. Metodická príručka na tvorbu výučbových materiálov na projektové vyučovanie. Vytváranie výučbových materiálov s využitím MS PowerPoint. Bratislava: P-mat, 2006. 54 s. ISBN 80-969414-6-1

- JAQUES, David. Learning in Groups. London: Kogan Page, 1991

- KRATOCHVÍlOVÁ, Jana; JANÍK,Tomáš. Projektové vyučování. Komenský. 2002, č. 2, s. 2-4. ISSN 0323-0449.

- $\quad$ KRATOCHVÍLOVÁ, Jana. Projektová metoda a projekt. Komenský. 2002, č. 2, s. 4-10. ISSN 0323-0449.

- MAZÁČOVÁ, Nataša. Vybrané pedagogické inovace $v$ současné škole: studijní text pro distanční studium. Praha: Univerzita Karlova v Praze, Pedagogická fakulta, 2008. 61 s. ISBN 978-80-7290-373-3

- PETLÁK, Erich. Projektové vyučovanie. Komenský. 2000, č. 9 - 10, s. 195-196. ISSN 03230449.

- $\quad$ PETRÁŠKOVÁ, Erika. Projektové vyučovanie. Prešov: Metodicko-pedagogické centrum, 2007. 82 s. ISBN $978-80-8045-463-0$ 
- PETTY, Geoffrey. Moderní vyučování. Praha: Portál, 2002. 380 s. ISBN 80-7178-681-0.

- SKALKOVÁ, Jarmila. Projektové vyučování a jeho realizace. Komenský. 1994, č. 5-6, s. 94-96. ISSN 0323-0449.

- SKALKOVÁ, Jarmila.: Za novou kvalitu vyučování. Brno: Paido 1995. 89 s. ISBN 80-8593111-7

- SKALKOVÁ, Jarmila. Obecná didaktika: vyučovací proces, učivo a jeho výběr, metody, organizační formy vyučování. 2. přepracované vydání. Praha: Grada, 2007. 328 s. ISBN 97880-247-1821-7

- ŠVECOVÁ, Milada. Teorie a praxe zařazení školních projektů ve výuce přírodopisu, biologie a ekologie. Praha: Karolinum, 2001. 79 s. ISBN 80-246-0227-X

- ŠVECOVÁ, Milada; MARTINCOVÁ, Eva. Školský projekt jako prostriedok výchovy k udržatelnému rozvoju. Banská Bystrica: Univerzita Mateja Bela, Fakulta prírodných vied, 2004. 94 s. ISBN 80-8083-016-9. 
Časopis Envigogika vydává Centrum pro otázky životního prostředí UK. Vývoj časopisu je podpořen projektem OP VK Mezioborová sít udržitelného rozvoje.

Více najdete na internetových stránkách projektu mosur.czp.cuni.cz


\section{MEZIOBOROVÁ SÍT} UDRŽITELNÉHO ROZVOJE

OP VK CZ.1.07/2.4.00/17.0130
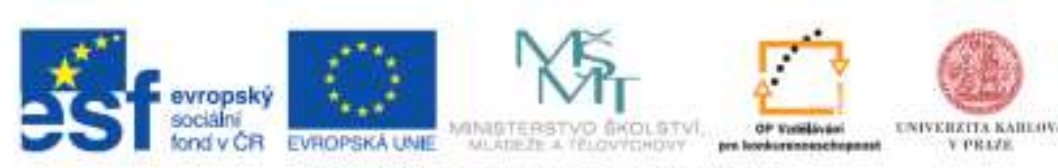

INVESTICE DO ROZVOUE VZDELAVANI 